\title{
Gender composition of ownership and management of firms and the gender digital divide in Africa
}

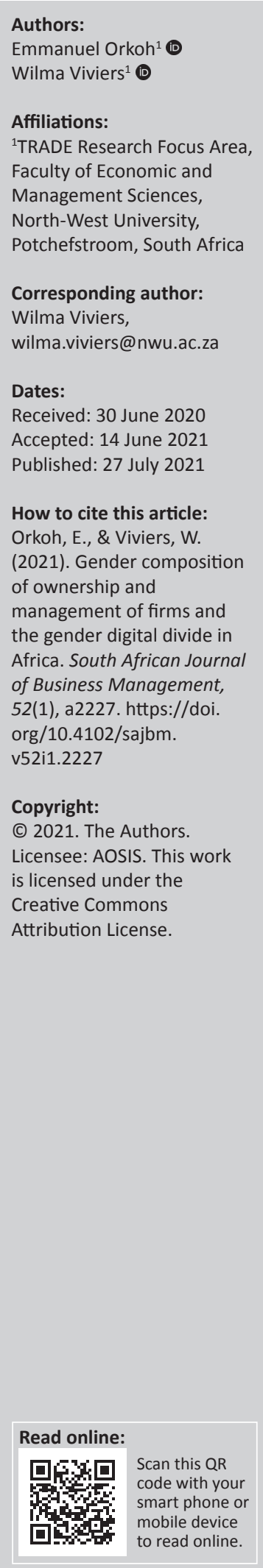

Purpose: This study analysed the determinants of firms' adoption and utilisation of digital technologies in Africa, with specific attention to the gender structure of firms' ownership and management, in the interest of closing the gender digital divide.

Design/methodology/approach: Logistic and Poisson regression techniques were used to analyse firm-level data from the World Bank's Enterprise Survey in 48 African countries for the period 2006-2019.

Findings/results: (1) Representation: The descriptive analysis shows very low representation of women in the ownership and management of firms in Africa. Whilst just over a quarter of the firms were partly women-owned, less than $10 \%$ are majority- or all-women-owned and only $12 \%$ have women as a top manager. The results are a comparison of firms according to gender composition. (2) Adoption: The regression estimates suggest that firms that are partly women-owned are more likely to adopt digital technologies, but all-women-owned and firms with women as top managers are less likely to adopt digital technologies for their business activities. These results on the adoption of digital technologies remained consistent with the results on utilisation of digital technologies for business activities. (3) Utilisation: Partly women-owned or women-led firms are less likely to use digital technologies for business activities such as using the Internet for research and placing orders. However, these firms are more likely to use e-mail for business communication. Partly women-owned firms are more likely to use digital technologies more intensively, whilst the opposite was observed for majority- or fully women-owned and women-led firms.

Practical implications: This study highlights the need for initiatives focussed on developing women in Africa's knowledge and use of digital technologies in business. Based on the results, women are urged to enhance their skills in this domain. This may present greater opportunities in terms of employment of women to increase women's representation.

Originality/value: The article contributes to knowledge on the nexus between gender digital divide and gender inequality in ownership and management of firms. The results may also inform initiatives to narrow the digital divide in Africa.

Keywords: digital technologies; digital divide; gender; management; ownership; firms; Africa.

\section{Introduction}

The use of digital technologies has become an indispensable requirement for firms to function effectively and stay competitive in the current digital era. The productivity-related and economic impact of information and communication technology (ICT) on firms has been extensively documented in literature (Bayo-Moriones, Billón, \& Lera-López, 2013; Forth \& Mason, 2004; Mason \& Hacker, 2003; Ravichandran, Liu, Han, \& Hasan, 2009; Tarute \& Gatautis, 2014). Some studies argue that ICT drives positive changes in firms' structure by rendering the information supervisory role of middle managers less useful, enabling top managers to directly communicate desired information and lowering the levels of decisionmaking process (Spanos, Prastacos, \& Poulymenakou, 2002). More importantly, small- and medium-sized enterprises (SMEs) that use new technologies are able to connect with larger corporations and become part of their operations. Such firms are able to surmount geographical barriers and connect with other small firms to pursue collaborative business activities (Forman, 2005).

Despite the documented relevance of digital technologies in business activities, literature suggests a marked digital divide amongst firms (Arendt, 2008; Middleton \& Chambers, 2010; Orser \& Riding, 2018). A digital divide can be defined as the gap between individuals, households, 
companies, regions and countries in terms of their access to, and utilisation of, ICT (Çilan, Bolat, \& Coşkun, 2009). The concept of the digital divide can be used to explain the socioeconomic differences arising from ICT use (BarzilaiNahon, 2006; Vehovar, Sicherl, Hüsing, \& Dolnicar, 2006) and the social, demographic and economic characteristics of the users (Bach, Zoroja, \& Vukšić, 2013).

Over the past decade, policymakers and researchers have paid attention to the gender dimension of the digital divide despite the paucity of statistical data disaggregated by gender to enhance the incorporation of gender issues into ICT policies, plans and strategies, particularly in developing countries (Antonio \& Tuffley, 2014; Liff, Shepherd, Wajcman, Rice, \& Hargittai, 2004; Mumporeze \& Prieler, 2017). Although no specific definition of the gender digital divide has been provided, there is a general consensus that it is not simply an issue of access but also of obstacles to internet usage (Kennedy, Wellman, \& Klement, 2003). Estimates show that, worldwide, some 327 million fewer women than men have a smartphone and can access the mobile Internet. There are more than 250 million fewer women online than men. The gap is decreasing in some regions, but increasing in others (ITU, 2017; OECD, 2018). Women are underrepresented in ICT jobs, with men being four times more likely to be ICT specialists. It is further reported that, at the age of 15 years, only $0.5 \%$ of girls wish to become ICT professionals, compared with $5 \%$ of boys (OECD, 2018).

This has significant implications for the gender gap in labour market outcomes and woman entrepreneurship. It may affect the ability of women-owned businesses to readily adapt to e-commerce platforms, which are increasingly adopted because of containment measurements related to the COVID-19 disease (Mastercard, 2020). Digital technologies can be used not only to support best practice but also as a tool to promote gender equality and empowerment of women, by enhancing their employment opportunities and increasing their access to knowledge and general information (Ikolo, 2013; OECD, 2018).

There is vast literature on gender, entrepreneurship and digital technology adoption (Chatterjee, Gupta, \& Upadhyay, 2020; Mack, Marie-Pierre, \& Redican, 2017; Orser \& Riding, 2018). However, what appears to be under-researched is the relationship between the gender digital divide and other forms of inequality, including in the ownership and management of firms, particularly in developing countries (Robinson et al., 2015). In this article, we set out to fill this gap in the literature by exploring the extent to which the gender composition of the ownership and management of firms is related to firms' adoption of digital technologies in their operations in Africa. Drawing on the literature on the gender digital divide (Aikins, 2019; Antonio \& Tuffley, 2014; Ikolo, 2013) and firms ownership and management structures (Marques, 2015; Saeed, Belghitar, \& Yousaf, 2016; Terjesen, Couto, \& Francisco, 2016), this study had two specific objectives: (1) to assess the effect of the gender composition of firm ownership on firms' adoption (ownership) and utilisation of digital technologies and (2) to examine the effect of the gender composition of firms' ownership and management on the intensity of firms' utilisation of digital technologies in Africa.

Addressing these objectives is important and timeous for women-owned and women-led businesses in Africa, as studies have shown that it is the only region in the world where there are more women than men entrepreneurs (Mastercard, 2020). However, women-owned enterprises post lower monthly profits ( $38 \%$ on average) than menowned enterprises, because of constraints such as a lack of capital and commercial practices such as advertising and marketing. Bardasi, Blackden and Guzman (2007) argue that the existence of gender-related barriers, including in digital technology adoption and utilisation for business activities, can thwart the economic potential of women as entrepreneurs and employees and could have an adverse impact on enterprise development, productivity and competitiveness. The results of this study could inform policy formulation towards addressing gender-specific barriers to entrepreneurship and leveraging the full participation of both men and women in the development of Africa's private sector, to unleash the continent's productive potential and strengthen its economic growth (Bardasi et al., 2007).

Competing explanations have been provided for the gender digital divide, mostly with reference to developed countries. On the one hand, women are perceived to be more technophobic than men, who are much better at using digital tools (Ha, Page, \& Thorsteinsson, 2011). On the other hand, some studies argue that women enthusiastically embrace digital communication (Hilbert, 2011). Several theories of technology adoption have evolved and been applied in the empirical literature to explain the determinants of the gender digital divide (Hafkin \& Huyer, 2007; Molina-Morales, Martínez-Cháfer, \& Valiente-Bordanova, 2019; Oliveira \& Martins, 2010; Orser \& Riding, 2018). These include the theory of reasoned action, the theory of planned behaviour (TPB), the technology acceptance model (TAM), the combined-TAM-TPB model, the motivational model, innovation diffusion theory, the model of PC utilisation, social cognitive theory and the unified theory of adoption and use of technology (Goswami \& Dutta, 2015).

However, the application of any theories to the adoption and utilisation of technologies must be context specific and tailored towards sociocultural factors that differently affect men and women (Njenga, 2018; Sabi, Uzoka, Langmia, \& Njeh, 2016). Considering the influence such sociocultural norms on gender roles in many African countries, Giddens's (1984) structuration theory was considered most appropriate for and applicable to the objectives, scope and context of this study. The theory posits that action and social structures operate as a duality and simultaneously affect each other. Through their actions, humans produce, reproduce and develop social structures, which become both constraints and enablers of their further actions (Nyandiere, Kamuzora, \& Lukandu, 2012). Later extensions to the theory suggest that the use of technology enhances deeper understanding of the fundamental role of social practices in the use and change of technologies in the workplace (Orlikowski, 2000, 2007). 
Social structures influence individuals' behaviour and thought about objects such as technology, even if their firm or agency is prepared to provide them the needed support to pursue their desire to adopt and use such technologies. These structures include cultural and psychological factors that may constrain certain people, particularly women, from using technologies, even when they have access (Terry \& Gomez, 2010). Dixon et al. (2014) distinguish between two types of access, namely: (1) cognitive access, which relates to individual resources (attitudes, anxiety and skills) used to access the technology, and (2) social access, which involves cultural norms and social resources embedded in a social group.

In the next sections of the article, we discuss the methodology, data and results of the analysis. The final section concludes the article with policy recommendations.

\section{Methodology}

In line with the objectives of this study, two estimation techniques were used for the analysis. As the dependent variables (adoption and utilisation of digital technologies) of the first objective were binary ( $Y e s$ or $\mathrm{No}$ ), logistic regression was used, which is one of the maximum likelihood estimation techniques. Following an earlier study (Katchova \& Miranda, 2004), we specified the logistic regression model as follows:

$\operatorname{In}\left(\frac{\rho_{i j t}^{k}}{1-\rho_{i j t}^{k}}\right)=\beta_{0}+\beta_{i} X_{i j t}^{k}$

Before interpreting Equation 1, it is important to note that the World Bank's Enterprise Survey (World Bank, 2020), which was the source of data for this study, followed firms based on their respective industries, by using the revised International Standard Industrial Classification (ISIC) code. The industries included in the various rounds of the survey were: manufacturing, construction, services, transport, storage and communications, whilst fully governmentowned firms were excluded. In line with the objectives of this study, Equation 1 included both adoption and utilisation of digital technology. In the equation, $\rho$ is the probability that firm $i$ in industry $k$, located in country $j$, would own or use a specific digital technology in its business at time $t$, whilst $\beta_{0}$ is the intercept of either the adoption or the utilisation of a given digital technology. Similarly, $\beta_{i}$ is a vector of the slope parameters, whilst $X_{i}$ is a set of correlates of digital technology adoption or utilisation. From Equation 1, the estimable function for digital technology adoption can be specified as Equation 2:

$$
\begin{aligned}
\operatorname{Prob}_{\left(\text {Digitech }_{i j t}^{k}=1 \mid X_{j t}^{k}\right)=} & \beta_{0}+\beta_{1} \text { Gender }_{i j t}^{k}+\beta_{2} \text { Firmsize }_{i j t}^{k}+ \\
& \beta_{3} \text { Educ }_{i j t}^{k}+\beta_{4} \text { Firmage }_{i j t}^{k}+ \\
& \beta_{5} \text { Ownership }_{i j t}^{k}+\beta_{6} \text { Public }_{i j t}^{k}+ \\
& \beta_{7} \text { Qassurance }_{i j t}^{k}+\beta_{8} \text { Electricity }_{i j t}^{k}+ \\
& \beta_{9} \text { City }_{i j t}^{k}+\beta_{10} \text { Labreg }_{i j t}^{k}+ \\
& \beta_{11} \text { Sector }_{i j t}^{k}+\varepsilon_{i j t}^{k}
\end{aligned}
$$

In Equation 2, Digitech represents a vector of the binary digital technology adoption and utilisation indicators. As presented in Table 1, the dependent variables used as proxies for firms' adoption of digital technology are: has fixed internet broadband, has a website and has both broadband and a website. The proxies for firms' digital utilisation are: e-mail used for business communication, the Internet used for placing orders and the Internet used for research. The estimated constant and slope parameters can be interpreted in the context of either odd ratios or marginal effects (Norton \& Dowd, 2018). However, in the interest of simplicity of interpretation and comparability of the estimates across different model specifications, this study used the marginal effects.

The a priori expectation was that the analysis would show that, regardless of the gender composition of the ownership and management structure, all firms are likely to adopt and use digital technologies in their business activities to remain competitive, improve performance and maximise profit. However, it is possible that the adoption of digital technologies will not necessarily translate into utilisation. Country-level and firm-specific factors, such as the cost of the Internet and the nature of economic activities in which the firm is engaged, may also influence both the likelihood of adoption and the extent of utilisation of digital technologies.

As the second objective of this study, the intensity or extent of firms' utilisation of digital technologies was explored on condition that the firms owned any of the digital noted technologies. We computed an additive index (standardised to $100 \%$ ) of the intensity of firms' use of digital technology (the Internet used for research, the Internet used for placing orders and e-mail used for business communication). As an index, 0 indicates no utilisation, whilst 100 represents full utilisation of the three digital technology indicators by a firm in its business activities. We employed Poisson regression to determine the correlates of intensity of digital technology utilisation.

The computed index had a considerable proportion of 0 observations because the original variables used for computing the index were binaries, which took the value 1 if the firm $u$ sed a particular digital technology and 0 otherwise. Where a variable has high 0 observations, potential estimation approaches are Poisson, tobit and linear regression. The Poisson regression has been found to be theoretically and empirically more sound in many circumstances, including when the data exhibit count element, which is why it is preferred for reliable estimates (Brown \& Dunn, 2011). The Poisson regression function is specified as Equation 3, with the error term $\epsilon$ :

$$
\begin{aligned}
\text { Digitindex }_{j t}^{k}= & \beta_{0}+\beta_{1} \text { Gender }_{i j t}^{k}+\beta_{2} \text { Firmsize }_{i j t}^{k}+\beta_{3} \text { Educ }_{i j t}^{k}+ \\
& \beta_{4} \text { Firmage }_{i j t}^{k}+\beta_{5} \text { Ownership }_{i j t}^{k}+\beta_{6} \text { Public }_{i j t}^{k}+ \\
& \beta_{7} \text { Lassurance }_{i j t}^{k}+\beta_{8} \text { Electricity }_{i j t}^{k}+\beta_{9} \text { City }_{i j t}^{k}+ \\
& \beta_{10} \text { Labreg }_{i j t}^{k}+\beta_{11} \text { Sector }_{i j t}^{k}+\varepsilon_{i j t}^{k}
\end{aligned}
$$


TABLE 1: Description of the variables included in the analysis.

\begin{tabular}{|c|c|c|c|c|}
\hline \multirow[t]{2}{*}{ Variable description } & \multirow[t]{2}{*}{ Variable measurement } & \multicolumn{3}{|c|}{ Observation $(N)$} \\
\hline & & Yes & No & Total \\
\hline \multicolumn{5}{|l|}{ Digital technology adoption indicators (Digitech) } \\
\hline Firm has a fixed internet broadband & Binary variable $(\mathrm{Yes}=1 ; \mathrm{No}=0)$ & 1709 & 3291 & 5000 \\
\hline Firm has a website & Binary variable $($ Yes $=1 ; \mathrm{No}=0)$ & 12577 & 27551 & 40128 \\
\hline Firm has both broadband and a website & Binary variable $($ Yes $=1 ; \mathrm{No}=0)$ & 871 & 39526 & 40397 \\
\hline \multicolumn{5}{|l|}{ Digital technology utilisation indicators (Digitech) } \\
\hline Internet used for research & Binary variable $($ Yes $=1 ; \mathrm{No}=0)$ & 336 & 1236 & 1572 \\
\hline E-mail used for business communication & Binary variable $($ Yes $=1 ; \mathrm{No}=0)$ & 19971 & 17388 & 37359 \\
\hline Digital technology utilisation intensity index (Digitindex) & $\begin{array}{l}\text { Continuous variable (index of Internet for research, Internet for } \\
\text { placing orders and e-mail for business communication) }\end{array}$ & - & - & 40397 \\
\hline \multicolumn{5}{|c|}{ Gender structure of firm's ownership and management indicators (Gender) } \\
\hline $\begin{array}{l}\text { Amongst the owners of the firm, are there any women? } \\
\text { (Partly women-owned firm) }\end{array}$ & Binary variable $($ Yes $=1 ; \mathrm{No}=0)$ & 9705 & 24526 & 34231 \\
\hline Is the top manager a woman? (Ref: Top manager is a man) & Binary variable $($ Yes $=1 ; \mathrm{No}=0)$ & 3450 & 36947 & 40397 \\
\hline Gender composition of firm's ownership & $\begin{array}{l}\text { Categorical variable with three responses-Category 2: Equally } \\
\text { divided between men and women }(\text { Yes }=1 ; \text { No }=0)\end{array}$ & 1251 & 27006 & 28257 \\
\hline Gender composition of firm's ownership & $\begin{array}{l}\text { Categorical variable with three responses-Category } 3 \text { : All/Majority } \\
\text { women-owned (Yes }=1 ; \mathrm{No}=0 \text { ) }\end{array}$ & 2691 & 25566 & 28257 \\
\hline \multicolumn{5}{|l|}{ Other explanatory (control) variables } \\
\hline Firm size (number of employees-Small) & Binary variable $(5-19$ employees $=1$; At least 20 employees $=0$ ) & 17041 & 23356 & 40397 \\
\hline Firm size (number of employees-Medium) & $\begin{array}{l}\text { Binary variable }(20-99 \text { employees }=1 \text {; Fewer than } 20 \text { and } 100+ \\
\text { employees }=0 \text { ) }\end{array}$ & 11647 & 28750 & 40397 \\
\hline Firm size (number of employees-Large) & Binary variable $100+$ employees $=1$; Fewer than 99 employees $=0$ ) & 5394 & 11647 & 40397 \\
\hline Education of the labour force & $\begin{array}{l}\text { Continuous variable (share of employees with secondary education } \\
\text { qualification) }\end{array}$ & - & - & 18232 \\
\hline Firm age (operation period) & Continuous variable (firm's years of operation) & - & - & 39421 \\
\hline Firm has foreign ownership & Binary variable $($ Yes $=1 ; \mathrm{No}=0)$ & 5099 & 35298 & 40397 \\
\hline Publicly traded firm & Binary variable $($ Yes $=1 ; \mathrm{No}=0)$ & 1819 & 38222 & 40041 \\
\hline $\begin{array}{l}\text { Firm has internationally recognised quality assurance } \\
\text { certification }\end{array}$ & Binary variable $($ Yes $=1 ; \mathrm{No}=0)$ & 5973 & 32767 & 38740 \\
\hline Views labour regulations an obstacle & Binary variable $($ Yes $=1 ; \mathrm{No}=0)$ & 10680 & 29121 & 39801 \\
\hline Access to electricity & Binary variable $($ Yes $=1 ; \mathrm{No}=0)$ & 31731 & 8443 & 40174 \\
\hline Sector of operation & Binary variable (Services sector $=1 ;$ Manufacturing sector $=0$ ) & 20851 & 19546 & 40397 \\
\hline
\end{tabular}

Source: Authors' computation based on data from World Bank. (2020). Enterprise surveys: Indicator descriptions. The World Bank. Retrieved from https://www.enterprisesurveys.org/en/data

It is important to note that there are different versions of the Poisson regression approach. We used the Poisson pseudo maximum likelihood (PPML) regression because of its applicability to any dependent variable with non-negative values, without the need to explicitly specify a distribution for the dependent variable (Correia, Guimarães, \& Zylkin, 2019).

We used two binary variables and one categorical variable as the measure of the gender structure of the firm. The first binary variable measured whether there were women amongst the owners of the firm, whilst the second binary variable measured whether the top manager of the firm was a woman. The third variable, which had five options $(1=$ all men, $2=$ majority men, 3 = equally divided, 4 = majority women and 5 = all women), measured the degree of gender distribution in the ownership of the firm. This variable was re-categorised into three $(1=$ all $/$ majority men, 2 = equally divided between men and women and $3=$ all/majority women), because of insufficient observation for the all women category in some of the initial regressions.

Following the literature (Aikins, 2019; Forman, 2005; Hilbert, 2011; Oliveira \& Martins, 2011), we accounted for the influence of firm-specific factors by including: size of firm, level of education of the workforce and type of ownership of the firm. We also included the following as proxies for the business environment and effectiveness of state institutions: quality assurance certification, geographical location of the firm, the firm holds the perception that labour regulations are an obstacle, access to electricity and the sector in which the firm operates.

Apart from the period of operation of the firm (firm age), the digital technology utilisation intensity index and the education of the workforce, all other variables were binary: 1 if the response was positive or the phenomenon was present, 0 if otherwise. Legal status of the firms was measured as a binary variable: 1 if the firm traded shares and 0 if otherwise. Education of the workforce was measured as the share of employees who had completed their secondary education.

It was expected that the size of the firm and the level of education of the workforce would be positively associated with both the adoption and utilisation of digital technologies. Firms' that adopt and use digital technologies maybe more formalised and easily identified by state institutions that are authorised to conduct regular quality assurance and enforce 
labour regulations. Firms that may not want to comply with such regulations maybe less likely to adopt and use digital technologies. It is therefore expected that firms that view labour regulations as an obstacle will be less likely to adopt and use digital technology compared with firms that hold contrary views. Similarly, firms that traded shares were expected to adopt and use digital technologies in their business activities. The geographical location of firms determines the availability of electricity and access to complementary resources such as the Internet. Access to electricity is an important determinant of firms' effective adoption and utilisation of digital technologies such as the Internet (Chinn \& Fairlie, 2007). We therefore expected that a firm located in the city would be more likely to adopt and use digital technologies than a firm located outside a city. In Africa, it is estimated that only $42.8 \%$ of the population had access to electricity in 2016, far less than any other developing region (Blimpo \& Cosgrove-Davies, 2019). Statistics indicate that, as in 2016, more than 600 million people in Africa lived without electricity, including more than $80 \%$ of rural residents (Blimpo \& Cosgrove-Davies, 2019). We expected that firms that faced obstacles in accessing electricity would be less likely to adopt and use digital technologies in their operations.

The nature of the association between the sector and the adoption and utilisation of digital technologies is dependent on the level of the firm's productivity (economic activity), its scope of operations and the relevance of the technology in question to its activities. Although firms in the services sector were expected to have adopted digital technologies, it was uncertain whether this positive association would be observed with regard to use.

\section{Data}

This study relied on pooled data for different firms extracted from the World Bank's Enterprise Surveys on firms in the services and manufacturing sectors in 48 African countries for all years in the period 2006-2019. Table 1-A1 in Appendix 1 presents the list of countries included in the analysis. Six countries were excluded because of non-availability of data (Algeria, Somalia, Seychelles, Comoros, São Tomé and Príncipe and Equatorial Guinea).

There was a risk that some firms would be included in multiple years, whilst others were dropped in some years and others included in some years. We minimised the potential effect of these on the estimates by including the industry (ISIC), country and year fixed effects (reported at the bottom of each output table as Yes).

The World Bank's Enterprise Surveys focus on factors (accommodating and constraining) that shape the business environment and play a critical role in driving or suppressing prosperity in a country. The World Bank (2017) describes an accommodating business environment as one that encourages firms to operate efficiently and provides incentives for innovation and increased productivity. These factors, in turn, spur employment creation and increase the tax base, both necessary to enable investment in public services such as health and education. Conversely, a disabling business environment creates impediments to business activities and inhibits a country's ability to realise its potential in terms of employment, productivity and citizens' welfare (World Bank, 2017).

The surveys under study, which have been conducted by the World Bank since the 1990s, covered a representative sample of small, medium and large companies (firms) in the nonagricultural, formal private economy, with target populations drawn from key manufacturing and service sectors in every region of the world (World Bank, 2009, 2017). With regard to scope, the surveys gather a wide range of qualitative and quantitative information from firms' managers and owners about the business environment in their countries and the productivity of their firms. The surveys cover core topics such as infrastructure, trade, finance, regulation, taxes and business licensing, corruption, crime and informality, innovation, labour and perceptions of obstacles to doing business. According to the World Bank (2017), the surveys are repeated from time to time, with the objective of tracking changes and benchmarking the effects of regulatory reforms on firms' performance.

Detailed explanations of the sampling and sample size (stratification, determination of the sample sizes) for each firm and country, as well as non-response rates, are provided in the World Bank's (2009) note Sampling methodology for the Enterprise Survey and Indicator Surveys, and the weighting process can be found in the technical note on weight computation. The note indicates that the survey follows a stratified random sampling approach. The population of industries (classified on the basis of revised ISIC codes) included in the surveys consists of manufacturing (Group D); construction (Group F); services (Groups $\mathrm{G}$ and $\mathrm{H}$ ); transport, storage and communications (Group I); and Subsector 72 (from Group $\mathrm{K})$, which are limited to establishments with five or more employees. As the World Bank's (2009) focus is the nonagricultural private sector, fully government-owned firms are excluded from the surveys.

The stratification process takes into account three criteria: sector of activity, firm size and geographical location. Firm size is further stratified into small (5-19 employees), medium (20-99 employees) and large (100+ employees). The sampling process ensures the fair representation of firms and sectors in each country, which allows for the generalisation of conclusions based on the results. The pooled data for the different countries in which the surveys were conducted in the period 2006-2019 yielded a total of 161000 firms in 144 countries. However, we restricted the analysis to 40397 firms in 48 African countries, as this was the context of focus in this study.

\section{Results and discussion}

The presentation and discussion of the results are preceded by a brief descriptive analysis of the variables of interest. As 
presented in Figure 1, the representation of women in both the ownership and management of firms in Africa is very low.

Whilst just over a quarter of the firms have some women as owners, less than $10 \%$ have a woman as the top manager. With regard to gender composition of firms' ownership, Figure 2 shows that the proportion of all/majority men-owned firms $(86 \%)$ was about eight times higher than the proportion of all/majority women-owned firms (10\%). Similarly, the proportion of majority men-owned firms was significantly higher than the proportion of majority women-owned firms.

These results confirm the earlier observation by the International Labour Organization that, despite some concrete affirmative action measures, women in Africa are under-represented in top decision-making roles (International Labour Organization, 2015). Chiloane-Tsoka (2012) attributes women's under-representation in key managerial and leadership positions to a number of sociocultural factors including gender stereotypes and unequal distribution of social roles, which disadvantage women.

A further cross tabulation of the gender distribution of the ownership and management of firms and firm-specific characteristics such as size and sector of operation showed that a relatively higher proportion of women-led and all or majority women-owned firms were operating on small scale

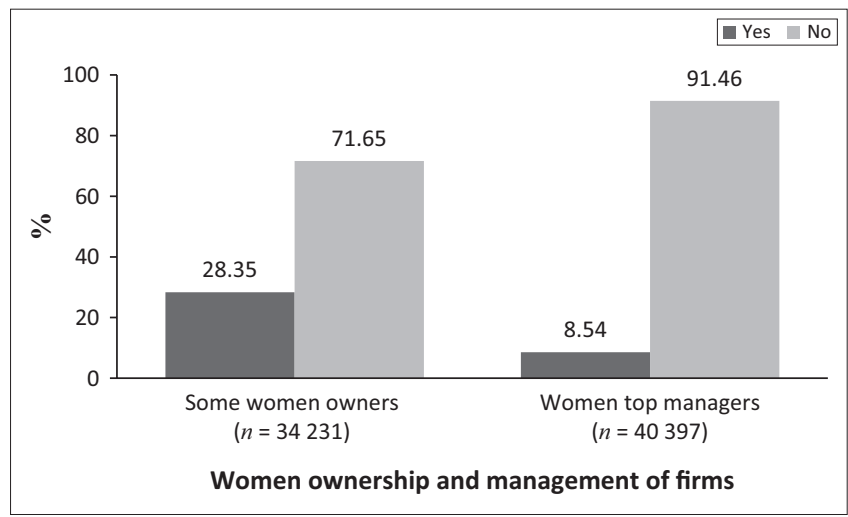

Source: Authors' computation based on data from World Bank. (2020). Enterprise surveys: Indicator descriptions. The World Bank. Retrieved from https://www.enterprisesurveys.org/ en/data

FIGURE 1: Gender composition of firms' ownership and management.

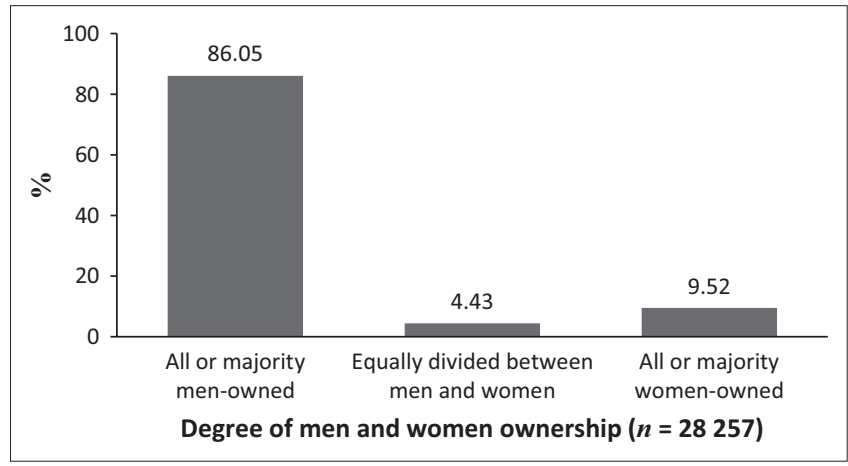

Source: Authors' computation based on data from World Bank. (2020). Enterprise surveys: Indicator descriptions. The World Bank. Retrieved from https://www.enterprisesurveys.org/ en/data

FIGURE 2: Gender composition of firms' ownership. whilst partly women-owned firms were operating on a large scale. The proportion of partly women-owned firms operating on small, medium and large scales were $26.72 \%$, $29.61 \%$ and $32.80 \%$ whilst all or majority women-owned firms that operated on small, medium and large scale were $12.25 \%, 7.12 \%$ and $4.06 \%$, respectively. Similarly, the proportion of women-led firms that operated on small, medium and large scale were $9.90 \%, 7.15 \%$ and $5.25 \%$. Within the manufacturing and service sectors, the proportion of partly women-owned firms were $27.15 \%$ and $29.53 \%$, all or majority women-owned firms were $7.97 \%$ and $10.90 \%$ and women-led firms were $6.86 \%$ and $10.11 \%$, respectively.

Similar to the gender composition of the ownership and management of firms, Figure 3 shows low rates of adoption of digital technology by firms in the countries under study.

The distribution depicts a relatively lower adoption of highspeed internet broadband (34\%) and a website (31\%). Only $2 \%$ of the firms had both high-speed internet broadband and a website. Some studies (Antonio \& Tuffley, 2014; Hashim, 2007) attribute the low adoption of digital technologies to factors such as exclusion from technology education and design, limited free time, gendered social norms and financial

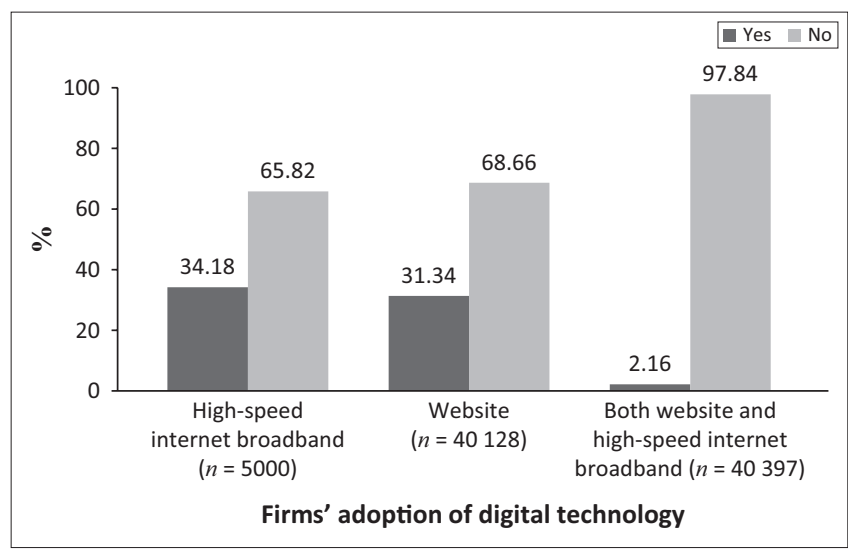

Source: Authors' computation based on data from World Bank. (2020). Enterprise surveys Indicator descriptions. The World Bank. Retrieved from https://www.enterprisesurveys.org/ en/data

FIGURE 3: Distribution of firms' adoption of digital technologies.

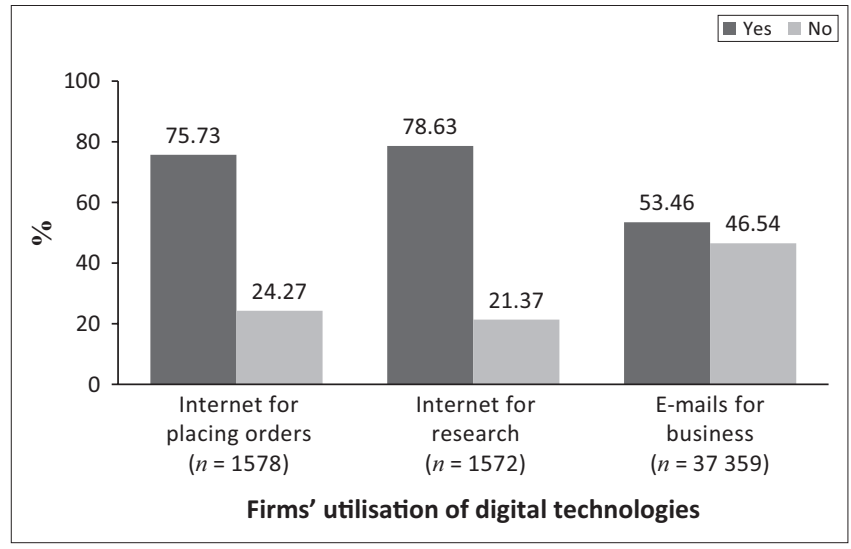

Source: Authors' computation based on data from World Bank. (2020). Enterprise surveys: Indicator descriptions. The World Bank. Retrieved from https://www.enterprisesurveys.org/ en/data

FIGURE 4: Firms' utilisation of digital technologies for business activities. 
TABLE 2: Correlates of firms' adoption of digital technologies for business activities.

\begin{tabular}{|c|c|c|c|c|c|c|c|c|c|c|c|c|}
\hline \multirow{3}{*}{$\begin{array}{l}\text { Dependent variable: } \\
\text { Digital technology }\end{array}$} & \multicolumn{6}{|c|}{ Some women owners } & \multicolumn{6}{|c|}{ Woman as top manager } \\
\hline & \multicolumn{2}{|c|}{ Broadband } & \multicolumn{2}{|c|}{ Website } & \multicolumn{2}{|c|}{ Both } & \multicolumn{2}{|c|}{ Broadband } & \multicolumn{2}{|c|}{ Website } & \multicolumn{2}{|c|}{ Both } \\
\hline & $\begin{array}{l}\text { Marginal } \\
\text { effects }\end{array}$ & $\begin{array}{l}\text { Standard } \\
\text { error }\end{array}$ & $\begin{array}{l}\text { Marginal } \\
\text { effects }\end{array}$ & $\begin{array}{l}\text { Standard } \\
\text { error }\end{array}$ & $\begin{array}{l}\text { Marginal } \\
\text { effects }\end{array}$ & $\begin{array}{l}\text { Standard } \\
\text { error }\end{array}$ & $\begin{array}{l}\text { Marginal } \\
\text { effects }\end{array}$ & $\begin{array}{l}\text { Standard } \\
\text { error }\end{array}$ & $\begin{array}{l}\text { Marginal } \\
\text { effects }\end{array}$ & $\begin{array}{c}\text { Standard } \\
\text { error }\end{array}$ & $\begin{array}{l}\text { Marginal } \\
\text { effects }\end{array}$ & $\begin{array}{c}\text { Standard } \\
\text { error }\end{array}$ \\
\hline Gender & $0.080 * *$ & 0.035 & $0.058 * * *$ & 0.009 & $0.003 * * *$ & 0.001 & $-0.053 * *$ & 0.051 & -0.019 & 0.013 & -0.001 & 0.001 \\
\hline Medium firm (Ref: Small) & $0.239 * * *$ & 0.036 & $0.238 * * *$ & 0.009 & $0.005 * * *$ & 0.001 & $0.231 * * *$ & 0.036 & $0.238 * * *$ & 0.009 & $0.005 * * *$ & 0.001 \\
\hline Large firm $(100+)$ & $0.297 * * *$ & 0.045 & $0.417 * * *$ & 0.014 & $0.008^{* * *}$ & 0.002 & $0.291 * * *$ & 0.044 & $0.415^{* * *}$ & 0.013 & $0.008^{* * *}$ & 0.002 \\
\hline Education of workforce & 0.001 & 0.001 & $0.002 * * *$ & 0.000 & $0.000 * * *$ & 0.000 & $0.001 *$ & 0.001 & $0.002 * * *$ & 0.000 & $0.000 * * *$ & 0.000 \\
\hline Firm age (operation period) & $0.006 * * *$ & 0.001 & $0.002 * * *$ & 0.000 & $0.000 * * *$ & 0.000 & $0.006 * * *$ & 0.001 & $0.002 * * *$ & 0.000 & $0.000 * * *$ & 0.000 \\
\hline Foreign-owned firm & 0.091 & 0.086 & $0.090 * * *$ & 0.014 & $-0.004 * * *$ & 0.001 & 0.066 & 0.081 & $0.095 * * *$ & 0.014 & $-0.004 * * *$ & 0.001 \\
\hline Publicly traded firm & 0.111 & 0.091 & $0.073 * * *$ & 0.019 & $0.002 * *$ & 0.001 & $0.161^{*}$ & 0.087 & $0.082 * * *$ & 0.018 & $0.003 * * *$ & 0.001 \\
\hline Quality certificate & $0.224 * * *$ & 0.051 & $0.289 * * *$ & 0.013 & $0.003 * * *$ & 0.001 & $0.219 * * *$ & 0.051 & $0.291 * * *$ & 0.013 & $0.003 * * *$ & 0.001 \\
\hline Firm located in a city & $0.137 * * *$ & 0.038 & $0.063 * * *$ & 0.009 & $0.005^{* * *}$ & 0.001 & $0.135 * * *$ & 0.038 & $0.066 * * *$ & 0.009 & $0.005 * * *$ & 0.001 \\
\hline Electricity & $0.193 * *$ & 0.091 & $-0.074 * * *$ & 0.010 & $0.009 * * *$ & 0.001 & $0.183^{* *}$ & 0.088 & $-0.070 * * *$ & 0.010 & $0.010 * * *$ & 0.001 \\
\hline Labour regulation & -0.049 & 0.050 & $0.046 * * *$ & 0.009 & $-0.006 * * *$ & 0.001 & -0.048 & 0.049 & $0.045 * * *$ & 0.009 & $-0.006 * * *$ & 0.001 \\
\hline Observations & 1,069 & - & 15,678 & - & 15,727 & - & 1,091 & - & 15,853 & - & 15,902 & - \\
\hline Wald chi ${ }^{2}$ & 167.720 & - & 2838.730 & - & 601.82 & - & 169.82 & - & 2850.850 & - & 590.220 & - \\
\hline Pseudo $\mathrm{R}^{2}$ & 0.162 & - & 0.191 & - & 0.261 & - & 0.159 & - & 0.191 & - & 0.248 & - \\
\hline Log likelihood & -619.391 & - & -8277.252 & - & -1061.922 & - & -634.342 & - & -8396.514 & - & -1095.088 & - \\
\hline Specification test (_hatsq) & 0.705 & - & 0.109 & - & 0.698 & - & 0.991 & - & 0.110 & - & 0.396 & - \\
\hline Goodness-of-fit & 0.2103 & - & 0.919 & - & 0.992 & - & 0.256 & - & 0.512 & - & 0.999 & - \\
\hline
\end{tabular}

Source: Authors' computation based on data from World Bank. (2020). Enterprise surveys: Indicator descriptions. The World Bank. Retrieved from https://www.enterprisesurveys.org/en/data $* * *, p<0.01 ; * *, p<0.05 ; *, p<0.1$.

and/or institutional constraints, most of which are particularly restrictive to women.

Adopting and owning digital technologies do not automatically translate into utilisation in business activities. However, the results in Figure 4 show a high rate of utilisation than the rate of adoption of digital technologies by firms. Thus, a higher proportion of firms that have adopted and own digital technologies use them for the intended research and business activities

Figure 4 also shows that firms in Africa least often use the Internet to conduct research. It is, however, encouraging that a little over half of the firms use e-mail for business communication. Whilst this descriptive analysis provides some ideas of the gender inequality in firm ownership and management, on the one hand, and firms' adoption and utilisation of digital technologies, on the other hand, it is not clear if, or how, the two phenomena are related. The regression estimates of this relationship are discussed in subsequent sections of this article.

\section{Estimates of digital technology adoption and utilisation}

As a requirement for validating the reliability and robustness of the regression estimates, the post-estimation results are reported at the bottom of each output table. Tables 2, 3 and 4 show the respective logistic regression estimates of firms' adoption and utilisation of digital technologies for business activities.

Two important post-estimation tests were conducted to validate the estimates: the Link Test (for the assessment of the model specification) and goodness-of-fit tests. The null hypothesis of the Link Test is that the model is an adequate fit to the data, whilst the alternative hypothesis indicates the need for additional modelling (Nunoo, Koomson, \& Orkoh, 2018). According to Ayenew (2014), the Link Test uses the linear predicted value (_hat) and linear predicted value squared (_hatsq) as the predictors to rebuild the model. The predicted variable _hat is expected to be a statistically significant predictor, unless the model is completely misspecified. This means that, if the model is properly specified, the square (_hatsq) of the predicted value (_hat) should not have much predictive power, except by chance. A significant_hatsq indicates an incorrectly specified model because of omission of relevant variable(s).

In the present study, the $p$-values of the specification (_hatsq) test were insignificant, indicating that meaningful predictors (correlates) had been included in the various models. These were indications that the models did not suffer from specification error. The Hosmer-Lemeshow goodness-of-fit test assesses the fitted model's overall departure from the observed data (Archer \& Lemeshow, 2006). The $p$-values of the test for goodness of fit of the models showed that the models were robust and fitted the observed data.

As indicated in the section on methodology, we present the results of separate specifications, in which each of the indicators of ownership and management structure of the firm is included in a particular digital technology model. The results reported in the output tables are marginal effects interpreted as percentages. The estimates of digital technology adoption shown in Table 2 indicate that, at 5\% and $1 \%$ levels of statistical significance, a firm with some women as owners is approximately $8.0 \%$ more likely to adopt a broadband internet connection and $6.0 \%$ more likely to have a website. Similarly, at a $1 \%$ level of significance, a firm 
TABLE 3: Correlates of firms' utilisation of digital technologies for business activities.

\begin{tabular}{|c|c|c|c|c|c|c|c|c|c|c|c|c|}
\hline \multirow{3}{*}{$\begin{array}{l}\text { Dependent variable: } \\
\text { Digital technology }\end{array}$} & \multicolumn{6}{|c|}{ Some women owners } & \multicolumn{6}{|c|}{ Woman as top manager } \\
\hline & \multicolumn{2}{|c|}{ Internet orders } & \multicolumn{2}{|c|}{ Internet research } & \multicolumn{2}{|c|}{ E-mail communication } & \multicolumn{2}{|c|}{ Internet orders } & \multicolumn{2}{|c|}{ Internet research } & \multicolumn{2}{|c|}{ E-mail communication } \\
\hline & $\begin{array}{l}\text { Marginal } \\
\text { effects }\end{array}$ & $\begin{array}{l}\text { Standard } \\
\text { error }\end{array}$ & $\begin{array}{l}\text { Marginal } \\
\text { effects }\end{array}$ & $\begin{array}{l}\text { Standard } \\
\text { error }\end{array}$ & $\begin{array}{l}\text { Marginal } \\
\text { effects }\end{array}$ & $\begin{array}{l}\text { Standard } \\
\text { error }\end{array}$ & $\begin{array}{l}\text { Marginal } \\
\text { effects }\end{array}$ & $\begin{array}{l}\text { Standard } \\
\text { error }\end{array}$ & $\begin{array}{c}\text { Marginal } \\
\text { effects }\end{array}$ & $\begin{array}{l}\text { Standard } \\
\text { error }\end{array}$ & $\begin{array}{l}\text { Marginal } \\
\text { effects }\end{array}$ & $\begin{array}{l}\text { Standard } \\
\text { error }\end{array}$ \\
\hline Gender & $-0.055^{*}$ & 0.032 & $-0.071 * *$ & 0.031 & $0.094 * * *$ & 0.011 & $-0.124 * * *$ & 0.039 & $-0.086 * *$ & 0.043 & -0.008 & 0.014 \\
\hline Medium firm (Ref: Small) & 0.066 & 0.041 & 0.032 & 0.043 & $0.277 * * *$ & 0.010 & 0.053 & 0.040 & 0.033 & 0.045 & $0.277^{* * *}$ & 0.010 \\
\hline Large firm $(100+)$ & 0.068 & 0.043 & $0.101^{* *}$ & 0.045 & $0.416 * * *$ & 0.011 & 0.055 & 0.042 & $0.104^{* *}$ & 0.046 & $0.413 * * *$ & 0.011 \\
\hline Firm age (operation period) & $0.001 * *$ & 0.001 & 0.000 & 0.001 & $0.002 * * *$ & 0.000 & 0.001 & 0.001 & 0.000 & 0.001 & $0.003 * * *$ & 0.000 \\
\hline Foreign-owned firm & -0.001 & 0.079 & 0.032 & 0.076 & $0.115 * * *$ & 0.018 & 0.019 & 0.073 & 0.007 & 0.066 & $0.109 * * *$ & 0.017 \\
\hline Publicly traded firm & -0.084 & 0.057 & 0.003 & 0.060 & $0.185 * * *$ & 0.027 & -0.085 & 0.055 & -0.041 & 0.055 & $0.193 * * *$ & 0.026 \\
\hline Quality certificate & 0.047 & 0.039 & 0.019 & 0.037 & $0.238 * * *$ & 0.018 & 0.055 & 0.039 & 0.017 & 0.037 & $0.237 * * *$ & 0.017 \\
\hline Firm located in a city & 0.031 & 0.033 & $0.115^{* * *}$ & 0.031 & $0.151 * * *$ & 0.009 & 0.019 & 0.034 & $0.118 * * *$ & 0.031 & $0.154 * * *$ & 0.009 \\
\hline Electricity & 0.017 & 0.076 & 0.031 & 0.069 & -0.003 & 0.012 & 0.027 & 0.077 & 0.024 & 0.075 & -0.000 & 0.011 \\
\hline Labour regulation & $-0.143 * * *$ & 0.036 & $-0.102 * * *$ & 0.038 & 0.010 & 0.010 & $-0.128 * * *$ & 0.036 & $-0.104 * * *$ & 0.037 & 0.009 & 0.010 \\
\hline Observations & 503 & - & 501 & - & 13967 & - & 510 & - & 508 & - & 14126 & - \\
\hline Wald chi ${ }^{2}$ & 33.410 & - & 39.880 & - & 2485.400 & - & 39.450 & - & 38.540 & - & 2449.260 & - \\
\hline Pseudo $R^{2}$ & 0.072 & - & 0.088 & - & 0.202 & - & 0.085 & - & 0.090 & - & 0.197 & - \\
\hline Log pseudolikelihood & -202.951 & - & -202.154 & - & -7591.754 & - & -201.221 & - & -205.869 & - & -7713.897 & - \\
\hline Specification test (_hatsq) & 0.608 & - & 0.360 & - & 0.238 & - & 0.313 & - & 0.260 & - & 0.524 & - \\
\hline Goodness-of-fit & 0.232 & - & 0.399 & - & 0.110 & - & 0.400 & - & 0.385 & - & 0.112 & - \\
\hline
\end{tabular}

Source: Authors' computation based on data from World Bank. (2020). Enterprise surveys: Indicator descriptions. The World Bank. Retrieved from https://www.enterprisesurveys.org/en/data $* * *, p<0.01 ; * *, p<0.05 ; *, p<0.1$.

that has some women as owners is approximately $0.3 \%$ more likely to have a website and broadband internet connection. The result is statistically significant with regard to the adoption of a website, but not high-speed broadband internet or both. Considering the gender composition of management, a firm that has a woman as top manager is less likely to adopt broadband, a website or both technologies; the results were statistically significant for high-broadband internet but not for website or indicators of digital technology.

The results for gender composition of firms' ownership as the explanatory variable (see Table 2-A1 in Appendix 1) showed that, compared with an all/majority men-owned firm, an all/majority women-owned firm is less likely to have either a website or a fixed broadband internet connection. We found a similar negative association between all-women-owned firms and the digital technology utilisation indicators. Also, a firm with equal distribution of men-and women-owners is more likely to adopt a website and use email for business communications, but less likely to use the Internet to place orders.

These observations are consistent with the general notion that a gender digital divide exists, especially in developing countries, indicating the urgent need for interventions and initiatives to address the causative issues, to ultimately ensure that no one is left behind, as envisioned in the African Union's Agenda 2063 and other global compacts (Kabaseke, 2018). More importantly, the results highlight socio-economic factors such as the cost of internet data, the nature of the educational system, gender stereotyping because of sociocultural norms and characteristics of individuals that are barriers to women's adoption and utilisation of digital technologies in Africa. An ITU report published in 2019 cited affordability as a major challenge in many countries, especially least developed countries (LDCs). It was reported that a fixed-broadband subscription including 5 GB of data costs less than $2 \%$ of Gross National Income (GNI) per capita in only 61 countries, whilst a mobile broadband subscription with a 1.5 GB data package costs less than $2 \%$ of GNI per capita in 89 countries, including four LDCs. Although the report was silent on gender distribution, it cited lack of skills as a barrier to effective use of the Internet (ITU, 2019).

Earlier studies identified limited access to physical infrastructure, illiteracy, social and cultural limitations, a lack of finance (affordability), lack of decision-making ability and segregation in employment as some of the barriers to women's adoption of digital technologies in Africa (Aikins, 2019; Ikolo, 2013). The importance of digital technologies for manufacturing, skills development, research and development, integration and intra-African trade, investment and tourism requires that policymakers pay particular attention to these sociocultural, economic and institutional factors that contribute to the gender-based digital divide at firm level on the African continent (African Union Commission, 2015).

In addition to gender composition, other firm-specific correlates that have a significantly positive association with the adoption of digital technologies for business activities are size of the firm, level of education of the workforce, years in operation and the firm's ownership structure. At a 1\% level of statistical significance, both medium (20-99 employees) and large (100+ employees) firms are more likely to adopt digital technologies in their operations, compared with small firms (fewer than 20 employees). We found that, at a $1 \%$ level of statistical significance, a $1 \%$ increase in the share of workers with a secondary education is associated with approximately 
TABLE 4: Poisson estimates of the intensity of digital technology utilisation.

\begin{tabular}{|c|c|c|c|c|c|c|c|c|}
\hline \multirow{3}{*}{$\begin{array}{l}\text { Dependent variable: Digital } \\
\text { technology utilisation index }\end{array}$} & \multicolumn{4}{|c|}{ Some women owners } & \multicolumn{4}{|c|}{ Woman as top manager } \\
\hline & \multicolumn{2}{|c|}{ Poisson } & \multicolumn{2}{|c|}{ PPML } & \multicolumn{2}{|c|}{ Poisson } & \multicolumn{2}{|c|}{ PPML } \\
\hline & Marginal effects & Standard error & Marginal effects & Standard error & Marginal effects & Standard error & Marginal effects & Standard error \\
\hline Gender & $0.150 * * *$ & 0.017 & $0.079 * * *$ & 0.014 & -0.023 & 0.026 & $-0.052 * *$ & 0.023 \\
\hline Medium firm (Ref: Small) & $0.414 * * *$ & 0.019 & $0.447 * * *$ & 0.016 & $0.418 * * *$ & 0.019 & $0.445 * * *$ & 0.016 \\
\hline Large firm $(100+)$ & $0.479 * * *$ & 0.024 & $0.533 * * *$ & 0.020 & $0.481 * * *$ & 0.024 & $0.531 * * *$ & 0.020 \\
\hline Education of workforce & $0.006 * * *$ & 0.000 & $0.004 * * *$ & 0.000 & $0.006 * * *$ & 0.000 & $0.004 * * *$ & 0.000 \\
\hline Foreign-owned firm & $0.039 *$ & 0.023 & $0.106 * * *$ & 0.019 & 0.028 & 0.022 & $0.094 * * *$ & 0.019 \\
\hline Publicly traded firm & $0.147 * * *$ & 0.026 & $0.036^{*}$ & 0.022 & $0.166 * * *$ & 0.026 & $0.050 * *$ & 0.021 \\
\hline Quality certificate & $0.225 * * *$ & 0.020 & $0.219 * * *$ & 0.016 & $0.224 * * *$ & 0.020 & $0.220 * * *$ & 0.016 \\
\hline Firm located in a city & $0.375 * * *$ & 0.016 & $0.160 * * *$ & 0.015 & $0.379 * * *$ & 0.016 & $0.161 * * *$ & 0.015 \\
\hline Electricity & $0.092 * * *$ & 0.019 & $0.087 * * *$ & 0.018 & $0.100 * * *$ & 0.019 & $0.088 * * *$ & 0.018 \\
\hline $\begin{array}{l}\text { Views labour legislation as an } \\
\text { obstacle }\end{array}$ & $-0.070 * * *$ & 0.017 & -0.009 & 0.015 & $-0.073 * * *$ & 0.017 & -0.009 & 0.014 \\
\hline Observations & 15727 & - & 14002 & - & 15902 & - & 14162 & - \\
\hline Country f.e./ ISIC f.e./ Year f.e. & Yes & - & Yes & - & Yes & - & Yes & - \\
\hline Wald $\mathrm{chi}^{2} / \mathrm{LR} \mathrm{chi}^{2}$ & 3440.400 & - & 2065.64 & - & 3339.340 & - & 2384.25 & - \\
\hline Log pseudolikelihood & -13695.739 & - & -13667.831 & - & -13896.033 & - & -12138.226 & - \\
\hline Pseudo $R^{2}$ & 0.068 & - & 0.070 & - & 0.066 & - & 0.123 & - \\
\hline Specification test (_hatsq) & 0.237 & - & 0.354 & - & 0.222 & - & 0.361 & - \\
\hline
\end{tabular}

Source: Authors' computation based on data from World Bank. (2020). Enterprise surveys: Indicator descriptions. The World Bank. Retrieved from https://www.enterprisesurveys.org/en/data PPML, Poisson pseudo-maximum likelihood.

$* * *, p<0.01$; **, $p<0.05 ; *, p<0.1$.

$0.2 \%$ increase in the likelihood of a firm having a website. It should be observed that firms that are majority foreignowned are more likely to adopt digital technologies than those locally owned. Also, firms that have achieved internationally recognised quality assurance certification and/or are located in the city are more likely to adopt digital technologies in their business operations than their counterparts that lack such certification and/or are located in geographical areas other than a city.

Consistent with the a priori expectation, a firm with publicly traded shares is much more likely to have a website for its operations than a firm that does not. However, such a firm is less likely than its counterparts to have both broadband and a website. With regard to access to electricity, the results indicate that firms that find access to electricity to be an obstacle are more likely to adopt internet broadband, but less likely to adopt the use of a website in their business activities. As the extent of the positive effect of access to electricity on broadband outweighs its negative effect on the adoption of website, the results for the adoption of both a website and internet broadband are also positive. These results were consistent, irrespective of the gender of the ownership of the firm.

Furthermore, a firm that perceives labour regulations to be an obstacle is more likely to have a website, but less likely to have broadband alone or both broadband and a website. Perhaps these results imply that firms that have a website are easily identified, in contrast to those without a website. As far as the sector of operation is concerned, a firm in the services sector is more likely to have a website compared with a firm in the manufacturing sector. It is evident from these results that a firm's adoption of digital technologies is influenced by other factors apart from the gender composition of its ownership and management.

Regarding the utilisation of digital technologies, the results in Table 3 show that, irrespective of the gender composition of ownership and management, a firm that is partly womenowned is less likely to use the Internet to place orders and for research purposes. However, at a $1 \%$ level of significance, a firm that is partly women-owned is more likely to use e-mail for business communication. The observed negative association between partly women-owned and women-led firms and the use of digital technologies supports the argument in the literature that the core issue in the digital revolution is the need to distinguish between access (referred to as adoption or ownership of technology in this study) of a digital network and utilisation, particularly with reference to those who are disadvantaged with regard to access to and training in ICT (Antonio \& Tuffley, 2014).

Although this study found evidence of a gender digital divide and unequal gender representation in the ownership and management of firms, what remains unknown is whether the identified divide supports the argument that women are at a natural disadvantage because they are less 'tech savvy' and more technophobic because the technology itself has not been designed to suit their needs (Hilbert, 2011) or because of institutional and infrastructure-related factors such as availability of electricity.

The results further show that, apart from the labour regulation being cited as an obstacle, all the other control variables (size, level of education of workforce, foreign 
ownership, quality assurance certification and geographical location) have a positive association with firms' utilisation of digital technologies. Firms that consider labour regulation an obstacle are less likely to use the Internet for either placing orders or conducting research. These results are consistent with the estimates of the intensity of digital technology utilisation shown in Table 3.

It can be seen from Table 3 that there are more significant correlates of e-mail for business communication than the use of the Internet to place orders and conduct research. Apart from the perception of labour regulations being an obstacle for firms, all the other correlates are statistically significant at the conventional levels. These variables are positively associated with the use of e-mail for business communication. The size of a firm is positively associated with the use of the Internet for research. It is intuitive to assume that large firms use the Internet for research, because of the scope and complexity of their operations. We also found that a firm that perceives labour regulations as an obstacle is less likely to use the Internet to place orders or for research purposes. At a $1 \%$ level of significance, a firm in the services sector is more likely to use e-mail for business communication than a firm in the manufacturing sector, all other things being equal.

This study also examined the likelihood and the intensity of the use of digital technologies (second objective). We present the results of the Poisson regression and the estimate of the PPML for comparison in Table 4. The results are consistent with those of the adoption of digital technologies. Use of digital technologies is high in firms that are partly womenowned, but low in firms where the top manager is a woman.

The use of digital technologies for all three purposes (using the Internet for research, using the Internet for placing orders and using e-mail for business communication) was shown to increase by approximately $8.0 \%$ for firms partly owned by women, compared with firms in which no women are owners. However, the intensity of utilisation of digital technologies reduces by about $5.0 \%$ for firms where the top manager is a woman, compared with firms in which the top manager is a man. Consistently across all the models, the results show that the differences in the adoption of digital technology by firms in Africa are not necessarily driven by owner/manager differences, but by differences in gender distribution of the ownership and whether the top manager is a man or a woman.

In addition, we observed a positive association between the size of a firm and the intensity of utilisation of digital technologies. The coefficients are relatively larger and more significant for medium and large firms than for small firms. It can also be observed that a percentage increase in the proportion of a firm's workforce with a secondary education increases the intensity of its utilisation of digital technologies by approximately $0.4 \%$. This implies that the level of education of the owners, the top manager and the employees of a firm is important for the firm's propensity to adopt and use digital technologies more intensively in its operations. This corroborates the conclusion of an earlier study by Forth and Mason (2004) that firms that have high proportion of educated workforce stand to benefit from lower cost of adopting and learning ICT whilst the inverse holds for a firm that has low proportion of well-educated workforce.

Unexpectedly, the lack of access to electricity does not seem to affect the intensity of utilisation of digital technologies, although it reduces the likelihood of adoption (see Tables 2 and 3). This could possibly be explained by the size or scale of operation and financial capacity of firms. Large firms may have the financial means to acquire substitute sources of electricity, such as generators and solar panels, making them less vulnerable to the impact of an unreliable power supply.

The longer a firm has been operating, the more intensively it uses digital technologies for the various business activities under study. Similarly, the intensity of the use of digital technologies is higher in a foreign-owned firm than in a domestically owned firm. Other significant correlates are publicly traded firms, quality certification and geographical location. A firm located in the city uses digital technologies more intensively than one located outside a city.

The heterogeneous effects of the various variables on digital technology adoption and utilisation in this analysis support the theoretical argument for a distinction between cognitive access (attitudes, anxiety and skills) and social access, which relates to cultural norms and social resources embedded in a social group (Dixon et al., 2014). Such clear distinctions are necessary to enhance proper policy formulation and implementation to identifying the factors that contribute to gender inequality in access to and utilisation of digital technologies in developing countries where both cognitive and social access remain a challenge. These findings reinforce the African Union's recognition of gender equality as a fundamental right and an integral part of regional integration, economic growth and social development. Gender equality and development of women are part of the African Union's Agenda 2063. This strategy, which include good governance that demands equal and effective participation by women and gender management systems to provide access and the investment of resources to support women and give them access to the necessary digital technology (African Union Commission, 2015).

\section{Conclusion}

This article contributes to the limited literature on the association between gender composition of the ownership and management of firms and the gender digital divide within the context of African countries. More importantly, it adds to the knowledge on how digital technology adoption and utilisation interact with the gender composition of the ownership and top management of firms. This study makes a contribution by distinguishing between firms' adoption and utilisation of digital technologies and contributes knowledge on the intensity of digital technology utilisation in 48 African countries for the period 2006-2019. 
The descriptive analysis reveals pervasive gender inequality in the ownership and management of firms and low adoption and utilisation of digital technologies in Africa. The regression estimates suggest that firms that are partly women-owned are more likely to adopt digital technologies (specifically, have a website and fixed broadband), but firms that are majority women-owned and all-women-owned, as well as firms with a woman as top manager, are less likely to adopt digital technologies for business activities (specifically, using the Internet for research and placing orders). These results are consistent with the utilisation of digital technologies for business activities. Partly women-owned and women-led firms are less likely to use digital technologies for business activities. However, these firms are more likely to use e-mail for business communication. Partly women-owned firms are more likely to use digital technologies more intensively, whilst the opposite is observed for all-women-owned and women-led firms.

Key observation from the analysis is that women's low representation in firms' ownership and management is associated with their low adoption and utilisation of digital technologies for business activities in Africa. Other important determinants of both the likelihood of adoption and utilisation (including intensity) of digital technologies are: size of the firm, level of education of the workforce, geographical location, sector of operation, access to electricity and other indicators of the business environment. These findings highlight the theoretical proposition for policymaking and implementation that recognise the need for a distinction between cognitive and social factors that influence digital technology adoption in especially developing countries where both factors are a societal challenge (Dixon et al., 2014).

In the light of these results, we recommend that government and the private sector design programmes that reduce the barriers to the adoption and utilisation of digital technologies. Such policies must target women's participation in digital technology education and address the sociocultural norms and gender stereotypes that discourage women from participating in the digital economy. Government should consider policies to reduce the cost of internet data, which small firms - often owned and led by women - cannot afford. Governments in Africa should also pay attention to other contributing factors, such as women's access to capital and their educational choices, which will influence their entrepreneurial and managerial decisions and, ultimately, the size and extent of operations of their businesses.

It is worth noting that one limitation of this study is the inability to complement the quantitative results with detailed qualitative explanation of women's adoption and utilisation of digital technologies. This could be explored in future studies, by using data that contain both quantitative and qualitative information on the variables of interest. Future studies should also explore the nature of businesses and individual-level factors, such as the number and ages of children that individuals have as indicators of barriers/differences between women and men in their adoption of digital technologies and ownership/management of firms in developing Africa.

\section{Acknowledgements}

The authors are grateful to the Enterprise Analysis Unit of the Development Economics Global Indicators Department of the World Bank Group for making the data available.

\section{Competing interests}

The authors declare that they have no financial or personal relationships, which may have inappropriately influenced them in writing this article.

\section{Authors' contributions}

E.O. and W.V. contributed equally to this work.

\section{Ethical considerations}

The authors confirmed that ethical clearance was not needed or required for the study. This article followed all ethical standards for research.

\section{Funding information}

This research received no specific grant from any funding agency in the public, commercial or not-for-profit sectors.

\section{Data availability}

The authors confirm that the data supporting the findings of this study are available within the article. The data used in this study were obtained and retrieved from the official website of the World Bank. This is open access data.

\section{Disclaimer}

The views and opinions expressed in this article are those of the authors and do not necessarily reflect the official policy or position of any affiliated agency of the authors.

\section{References}

African Union Commission. (2015). Agenda 2063: The Africa we want (Final edn.). African Union. Retrieved from https://www.un.org/en/africa/osaa/pdf/au/ agenda2063.pdf

Aikins, S.K. (2019). Determinants of digital divide in Africa and policy implications International Journal of Public Administration in the Digital Age, 6(1), 64-79. https://doi.org/10.4018/IJPADA.2019010104

Antonio, A., \& Tuffley, D. (2014). The gender digital divide in developing countries. Future Internet, 6(4), 673-687. https://doi.org/10.3390/fi6040673

Archer, K.J., \& Lemeshow, S. (2006). Goodness-of-fit test for a logistic regression model fitted using survey sample data. The Stata Journal, 6(1), 97-105. https:// model fitted using survey sample data.
doi.org/10.1177/1536867X0600600106

Arendt, L. (2008). Barriers to ICT adoption in SMEs: How to bridge the digital divide? Journal of Systems and Information Technology, 10(2), 93-108. https://doi. org/10.1108/13287260810897738

Ayenew, W. (2014). The determinant of saving behavior of women in urban Ethiopia. In case of Arba Minch town. Developing Country Studies, 4(21), 130-139.

Bach, M.P., Zoroja, J., \& Vukšić, V.B. (2013). Determinants of firms' digital divide: A review of recent research. Procedia Technology, 9, 120-128. https://doi. org/10.1016/j.protcy.2013.12.013

Bardasi, E., Blackden, C.M., \& Guzman, J.C. (2007). Gender, entrepreneurship, and competitiveness in Africa. Africa Competitiveness Report, 1, 69-85.

Barzilai-Nahon, K. (2006). Gaps and bits: Conceptualizing measurements for digita divide/s. The Information Society, 22(5), 269-278. https://doi. org/10.1080/01972240600903953

Bayo-Moriones, A., Billón, M., \& Lera-López, F. (2013). Perceived performance effects of ICT in manufacturing SMEs. Industrial Management \& Data Systems, 113(1), 117-135. https://doi.org/10.1108/02635571311289700 
Blimpo, M.P., \& Cosgrove-Davies, M. (2019). Electricity access in sub-Saharan Africa: Uptake, reliability, and complementary factors for economic impact. Washington, Uptake, reliability, and
DC: The World Bank.

Brown, J.E., \& Dunn, P.K. (2011). Comparisons of tobit, linear, and Poisson-gamma regression models: An application of time use data. Sociological Methods \& Research, 4O(3), 511-535. https://doi.org/10.1177/0049124111415370

Chatterjee, S., Gupta, S.D., \& Upadhyay, P. (2020). Technology adoption and entrepreneurial orientation for rural women: Evidence from India. Technological Forecasting and Social Change, 160, 120236. https://doi.org/10.1016/j. techfore.2020.120236

Chiloane-Tsoka, E.G. (2012). Cultural observations facing women managers: A South African perspective. Gender and Behaviour, 10(2), 4949-4973.

Chinn, M.D., \& Fairlie, R.W. (2007). The determinants of the global digital divide: A cross-country analysis of computer and internet penetration. Oxford Economic Papers, 59(1), 16-44. https://doi.org/10.1093/oep/gpl024

Çilan, C..A., Bolat, B.A., \& Coşkun, E. (2009). Analyzing digital divide within and between member and candidate countries of European Union. Government Information Quarterly, 26(1), 98-105. https://doi.org/10.1016/j.giq.2007.11.002

Correia, S., Guimarães, P., \& Zylkin, T. (2019). PPMLHDFE: Fast Poisson estimation with high-dimensional fixed effects. The Stata Journal, 20(1), 95-115.

Dixon, L.J., Correa, T., Straubhaar, J., Covarrubias, L., Graber, D., Spence, J., \& Rojas, V. (2014). Gendered space: The digital divide between male and female users in internet public access sites. Journal of Computer-Mediated Communication, 19(4), 991-1009. https://doi.org/10.1111/jcc4.12088

Forman, C. (2005). The corporate digital divide: Determinants of internet adoption. Management Science, 51(4), 641-654. https://doi.org/10.1287/mnsc.1040. 0343

Forth, J., \& Mason, G. (2004). Information and communication technology (ICT) adoption and utilisation, skill constraints and firm level performance: Evidence from UK benchmarking surveys. London: National Institute of Economic and Social Research.

Giddens, A. (1984). The constitution of society: Outline of the theory of structuration. Berkeley, CA: University of California Press.

Goswami, A., \& Dutta, S. (2015). Gender differences in technology usage - A literature review. Open Journal of Business and Management, 4(1), 51-59. https://doi. org/10.4236/ojbm.2016.41006

Ha, J.G., Page, T., \& Thorsteinsson, G. (2011). A study on technophobia and mobile device design. International Journal of Contents, 7(2), 17-25. https://doi. org/10.5392/IJoC.2011.7.2.017

Hafkin, N.J., \& Huyer, S. (2007). Women and gender in ICT statistics and indicators for development. Information Technologies \& International Development, 4(2), 25-41. https://doi.org/10.1162/itid.2008.00006

Hashim, J. (2007). Information communication technology (ICT) adoption among SME owners in Malaysia. International Journal of Business and Information, 2(2), 221-239.

Hilbert, M. (2011). Digital gender divide or technologically empowered women in developing countries? A typical case of lies, damned lies, and statistics. Women's Studies International Forum, 34(6), 479-489. https://doi.org/10.1016/j. wsif.2011.07.001

Ikolo, V.E. (2013). Gender digital divide and national ICT policies in Africa. In M Khosrow-Pour (Eds.). Digital literacy: Concepts, methodologies, tools, and applications (pp. 812-832). Hershey, PA: IGI Global.

International Labour Organization. (2015). Women in business and management Gaining momentum. Abridged Version of the Global Report International Labour Office. Geneva.

The International Telecommunication Union (ITU). (2017). ICT facts and figures 2017. Geneva: The International Telecommunication Union (ITU). Retrieved from http:// www.itu.int/en/ITUD/Statistics/Documents/facts/ICTFactsFigures2017.pdf

The International Telecommunication Union (ITU). (2019). Measuring digital development: Facts and figures 2019. International Telecommunication Union. development: Facts and
Geneva: ITU Publications.

Kabaseke, C. (2018). Equality or pipe dreams: gender and inclusive development under the African Union's Agenda 2063. Journal of Comparative Law in Africa, 5(2), 73-97.

Katchova, A.L., \& Miranda, M.J. (2004). Two-step econometric estimation of farm characteristics affecting marketing contract decisions. American Journal of Agricultural Economics, 86(1), 88-102. https://doi.org/10.1111/j.0092-5853.2004.00564.x

Kennedy, T., Wellman, B., \& Klement, K. (2003). Gendering the digital divide. IT \& Society, 1(5), 72-96. https://doi.org/10.1353/ctt.2003.0009

Liff, S., Shepherd, A., Wajcman, J., Rice, R., \& Hargittai, E. (2004). An evolving gender digital divide? OII Internet Issue Brief 2(1), 1-17. https://doi.org/10.2139/ ssrn.1308492

Mack, E.A., Marie-Pierre, L., \& Redican, K. (2017). Entrepreneurs' use of internet and social media applications. Telecommunications Policy, 41(2), 120-139. https://doi. org/10.1016/j.telpol.2016.12.001

Marques, H. (2015). Does the gender of top managers and owners matter for firm exports? Feminist Economics, 21(4), 89-117. https://doi.org/10.1080/13545701. 2015.1029958

Mason, S.M., \& Hacker, K.L. (2003). Applying communication theory to digital divide research. IT \& Society, 1(5), 40-55.
Mastercard. (2020). The Mastercard index of women entrepreneurs 2020 report. Retrieved from https://mastercardcontentexchange.com/research-reports/2020/ mastercard-index-of-women-entrepreneurs/

Middleton, K.L., \& Chambers, V. (2010). Approaching digital equity: Is wifi the new leveler? Information Technology \& People, 23(1), 4-22. https://doi. org/10.1108/09593841011022528

Molina-Morales, F.X., Martínez-Cháfer, L., \& Valiente-Bordanova, D. (2019). Disruptive technology adoption, particularities of clustered firms. Entrepreneurship \& Regional Development, 31(1-2), 62-81. https://doi.org/10.1080/08985626.2018. 1537147

Mumporeze, N., \& Prieler, M. (2017). Gender digital divide in Rwanda: A qualitative analysis of socioeconomic factors. Telematics and Informatics, 34(7), 1285-1293. https://doi.org/10.1016/j.tele.2017.05.014

Njenga, J.K. (2018). Sociocultural paradoxes and issues in e-learning use in higher education Africa. Globalisation, Societies and Education, 16(1), 120-133. https:// doi.org/10.1080/14767724.2017.1390664

Norton, E.C., \& Dowd, B.E. (2018). Log odds and the interpretation of logit models. Health Services Research, 53(2), 859-878. https://doi.org/10.1111/14756773.12712

Nunoo, J., Koomson, I., \& Orkoh, E. (2018). Household deficiency in demand for water: Do water source and travel time matter?', Global Social Welfare, 5(3), 179-187. https://doi.org/10.1007/s40609-017-0092-6

Nyandiere, C.M., Kamuzora, F., \& Lukandu, I.A. (2012). Application of structuration theory and activity theory in enterprise resources planning systems implementation for universities. Computer Technology and Application, 3(5), 383-392.

Organisation for Economic Co-Operation Development (OECD). (2018). Bridging the digital gender divide: Include, upskill, innovate. Paris: Organisation for Economic digital gender divide: Include,
Co-Operation Development.

Orlikowski, W.J. (2000). Using technology and constituting structures: A practice lens for studying technology in organizations. Organization science, 11(4), 404-428.

Orlikowski, W.J. (2007). Sociomaterial practices: Exploring technology at work. Organization studies, 28(9), 1435-1448.

Oliveira, T., \& Martins, M.F. (2010). Information technology adoption models at firm level: Review of literature. Paper presented at the European Conference on Information Systems Management (pp. 312-313), 09-10 September 2010. Reading: Academic Conferences Ltd.

Oliveira, T., \& Martins, M.F. (2011). Literature review of information technology adoption models at firm level. Electronic Journal of Information Systems Evaluation, 14(1), 110.

Orser, B., \& Riding, A. (2018). The influence of gender on the adoption of technology among SMEs. International Journal of Entrepreneurship and Small Business, 33(4) 514-531. https://doi.org/10.1504/IJESB.2018.10011218

Ravichandran, T., Liu, Y., Han, S., \& Hasan, I. (2009). Diversification and firm performance: Exploring the moderating effects of information technology spending. Journal of Management Information Systems, 25(4), 205-240. https:// spending. Journal of Management Informa
doi.org/10.2753/MIS0742-1222250407

Robinson, L., Cotten, S.R., Ono, H., Quan-Haase, A., Mesch, G., Chen, W., \& Stern, M.J. (2015). Digital inequalities and why they matter. Information, Communication \& Society, 18(5), 569-582. https://doi.org/10.1080/1369118X.2015.1012532

Sabi, H.M., Uzoka, F.M.E., Langmia, K., \& Njeh, F.N. (2016). Conceptualizing a model for adoption of cloud computing in education. International Journal of Information Management, 36(2), 183-191. https://doi.org/10.1016/j. ijinfomgt.2015.11.010

Saeed, A., Belghitar, Y., \& Yousaf, A. (2016). Firm-level determinants of gender diversity in the boardrooms: Evidence from some emerging markets. International Business Review, 25(5), 1076-1088. https://doi.org/10.1016/j.ibusrev.2016.01.002

Spanos, Y.E., Prastacos, G.P., \& Poulymenakou, A. (2002). The relationship between information and communication technologies adoption and management. Information \& Management, 39(8), 659-675. https://doi.org/10.1016/S03787206(01)00141-0

Tarutè, A., \& Gatautis, R. (2014). ICT impact on SMEs' performance. Procedia-Socia and Behavioral Sciences, 110, 1218-1225. https://doi.org/10.1016/j.sbspro. 2013.12.968

Terjesen, S., Couto, E.B., \& Francisco, P.M. (2016). Does the presence of independent and female directors impact firm performance? A multi-country study of board diversity. Journal of Management \& Governance, 20(3), 447-483. https://doi. org/10.1007/s10997-014-9307-8

Terry, A., \& Gomez, R. (2010). Gender and public access computing: An international perspective. The Electronic Journal of Information Systems in Developing Countries, 43(1), 1-17. https://doi.org/10.1002/j.1681-4835.2010.tb00309.x

Vehovar, V., Sicherl, P., Hüsing, T., \& Dolnicar, V. (2006). Methodological challenges of digital divide measurements. The Information Society, 22(5), 279-290. https:// doi.org/10.1080/01972240600904076

World Bank. (2009). Enterprise surveys and indicators surveys: Sampling methodology. The World Bank. Retrieved from www.enterprisesurveys.org

World Bank. (2017). Enterprise surveys: Indicator descriptions: The World Bank. Retrieved from http://www.enterprisesurveys.org

World Bank. (2020). Enterprise surveys: Indicator descriptions. The World Bank. Retrieved from https://www.enterprisesurveys.org/en/data 


\section{Appendix 1}

TABLE 1-A1: Descriptive statistics of countries included in the analysis.

\begin{tabular}{|c|c|c|c|}
\hline Number & Countries & Frequency & $\%$ \\
\hline 1 & Angola & 785 & 1.94 \\
\hline 2 & Benin & 300 & 0.74 \\
\hline 3 & Botswana & 610 & 1.51 \\
\hline 4 & Burkina Faso & 394 & 0.98 \\
\hline 5 & Burundi & 427 & 1.06 \\
\hline 6 & Cabo Verde & 156 & 0.39 \\
\hline 7 & Cameroon & 724 & 1.79 \\
\hline 8 & Central African Republic & 150 & 0.37 \\
\hline 9 & Chad & 303 & 0.75 \\
\hline 10 & Congo, Democratic Republic & 1,228 & 3.04 \\
\hline 11 & Congo, Republic & 151 & 0.37 \\
\hline 12 & Cote d'Ivoire & 887 & 2.20 \\
\hline 13 & Djibouti & 266 & 0.66 \\
\hline 14 & Egypt & 4,711 & 11.66 \\
\hline 15 & Eritrea & 179 & 0.44 \\
\hline 16 & Eswatini & 457 & 1.13 \\
\hline 17 & Ethiopia & 1,492 & 3.69 \\
\hline 18 & Gabon & 179 & 0.44 \\
\hline 19 & Gambia & 151 & 0.37 \\
\hline 20 & Gambia, The & 174 & 0.43 \\
\hline 21 & Ghana & 1,214 & 3.01 \\
\hline 22 & Guinea & 373 & 0.92 \\
\hline 23 & Guinea-Bissau & 159 & 0.39 \\
\hline 24 & Kenya & 2,439 & 6.04 \\
\hline 25 & Lesotho & 301 & 0.75 \\
\hline 26 & Liberia & 301 & 0.75 \\
\hline 27 & Madagascar & 977 & 2.42 \\
\hline 28 & Malawi & 673 & 1.67 \\
\hline 29 & Mali & 1,035 & 2.56 \\
\hline 30 & Mauritania & 387 & 0.96 \\
\hline 31 & Mauritius & 398 & 0.99 \\
\hline 32 & Morocco & 1,503 & 3.72 \\
\hline 33 & Mozambique & 1,080 & 2.67 \\
\hline 34 & Namibia & 909 & 2.25 \\
\hline 35 & Niger & 301 & 0.75 \\
\hline 36 & Nigeria & 4,567 & 11.31 \\
\hline 37 & Rwanda & 453 & 1.12 \\
\hline 38 & Senegal & 1,107 & 2.74 \\
\hline 39 & Sierra Leone & 302 & 0.75 \\
\hline 40 & South Africa & 937 & 2.32 \\
\hline 41 & South Sudan & 738 & 1.83 \\
\hline 42 & Sudan & 662 & 1.64 \\
\hline 43 & Tanzania & 1,232 & 3.05 \\
\hline 44 & Togo & 305 & 0.76 \\
\hline 45 & Tunisia & 592 & 1.47 \\
\hline 46 & Uganda & 1,325 & 3.28 \\
\hline 47 & Zambia & 1,204 & 2.98 \\
\hline 48 & Zimbabwe & 1,199 & 2.97 \\
\hline - & Total & 40,397 & 100.00 \\
\hline
\end{tabular}

Source: Authors' computation based on data from World Bank. (2020). Enterprise surveys: Indicator descriptions. The World Bank. Retrieved from https://www.enterprisesurveys.org/ en/data 


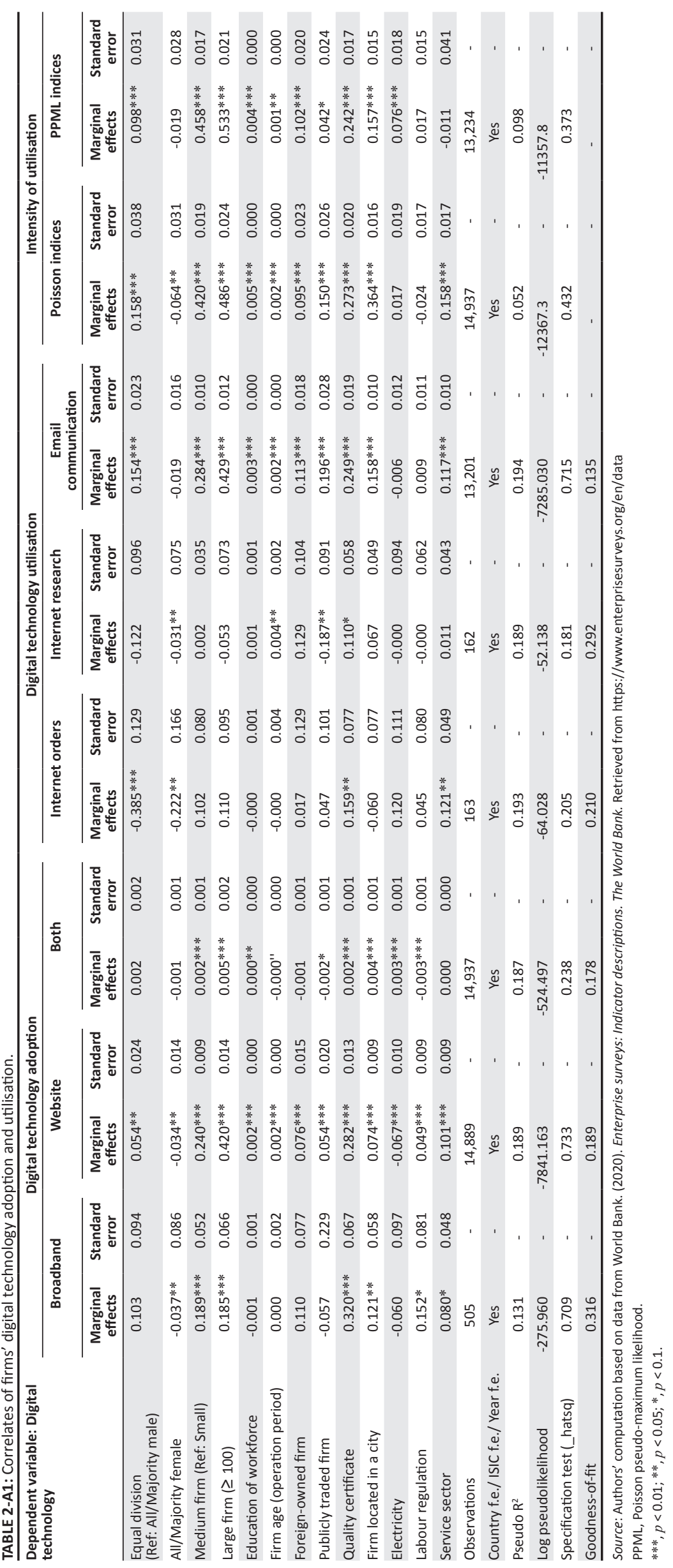

